\title{
A clinicopathological study of lesions of bone
}

\author{
Dnyanada Kokode* \\ Department of Pathology, NKP Salve Institute of Medical Sciences and Research Centre, Nagpur-440019, India
}

\begin{abstract}
Introduction: Bone tumours are neoplasms originating in the skeletal system that are within or closely related to the bone tissue. A spectrum of pathological bone lesions can present in any form from inflammatory to neoplastic conditions. They account for $0.2 \%$ of all tumours in humans.

Aims and objectives: To study the clinical and pathological spectrum of lesions of bone.

Material and methods: This study was carried out in the Department of Pathology, in a Tertiary health care hospital. It was a hospital based cross sectional study. After obtaining detailed clinical history and examination, biopsies and resected specimen were received in $10 \%$ formalin, gross findings were noted and histopathological examination was done.

Results: Histopathological evaluation was done in all 106 cases, obtained in a period of 2 years in the tertiary care hospital. In this study, non-neoplastic and benign neoplastic were the commonest bone lesions which accounted for $40.6 \%$ each, followed by malignant lesions $15.1 \%$ and metastatic lesions $3.7 \%$. The maximum number of bone lesions occurred in second decade of life with a male to female ratio of 1.35:1. The most common presenting feature of all bone lesions was pain. The commonest site of all bone lesions in this study was lower end of femur followed by proximal end of tibia. The most common benign neoplatic neoplasms in this study was giant cell tumour followed by Osteochondroma. Among malignant neoplasm the most common was Osteosarcoma. Epithelial malignancies were the most common to metastasise to bone.
\end{abstract}

Conclusion: Histopathology is the gold standard for the precise diagnosis of the vast number of bone lesions. Since the exact diagnosis of bone tumours is at times difficult, a joint approach integrating clinical, radiological and histopathological findings is necessary to increase accuracy.

\section{Introduction}

Bone tumours are neoplasms originating in the skeletal system that are within or closely related to the bone tissue [1,2]. A spectrum of pathological bone lesions can present in any form from inflammatory to neoplastic conditions [1,2]. These lesions are diverse in their clinical and morphological features and range in behaviour from innocuous to rapidly fatal [3]. Accurate diagnosis, proper staging and appropriate treatment are thus necessary to ensure maximum patient survival and maintain optimal function of the affected body parts [4].

Primary bone tumours are relatively uncommon lesions [5]. They account for $0.2 \%$ of all tumours in humans and some of these tumours display marked inter- and intranational variations in incidence, site and age distribution [6]. Some relevant demographic features like age, gender and skeletal site are important factors while making a diagnosis $[1,7,8]$. The lesions predominantly occur in two age groups: adults over 40 years of age and children in the first and second decade of life. Various etiological agents including chemotherapy, radiation, trauma, infections and pre-existing bone lesions have been implicated. Common presentations are progressive pain, swelling, tenderness, restriction in joint mobility and pathological fracture in some of the cases $[2,9]$.

In an Indian study, the most common bone involved was femur [4]. In chronic osteomyelitis and tuberculous lesions; femur and vertebrae respectively are known to be involved commonly. However, some benign processes such as osteomyelitis can mimic malignant tumours, and some malignant lesions such as metastases or myeloma, can mimic benign $[3,4]$.

\section{Aims and objectives}

To study the clinical and pathological spectrum of lesions of bone.

\section{Material and methods}

This study was carried out in the Department of Pathology, in a Tertiary health care hospital after obtaining Institutional Ethics Committee Clearance. It was a hospital based cross sectional study. Patients presenting with lesions in bone of all age groups and both sexes were included in the research study. Detailed clinical history, radio logical findings and other investigations were noted. FNAC was done wherever possible. All bone biopsies and resected specimens received during a period of 2 years were studied. Biopsies and resected specimen were received in $10 \%$ formalin and gross findings were noted. Tissues were processed and stained with routine haematoxylin and eosin stain. Histopathological examination was done under light microscope.

\section{Results}

Histopathological evaluation was done in all 106 cases, obtained in a period of 2 years in the tertiary care hospital. In this study, nonneoplastic and benign neoplastic were the commonest bone lesions which accounted for $40.6 \%$ each, followed by malignant lesions $15.1 \%$ and metastatic lesions $3.7 \%$.

${ }^{\star}$ Correspondence to: Dnyanada Kokode, Department of Pathology, NKP Salve Institute of Medical Sciences and Research Centre, Nagpur-440019, India, E-mail: dr.radhakokode@gmail.com

Received: February 06, 2019; Accepted: February 20, 2019; Published: February 25,2019 
In this study the age of patients varied from 9 years to 81 years. The mean age was 29.72 years. There was an overall male preponderance with a male to female ratio of 1.35:1. The maximum number of bone lesions occurred in the age group of 11-20 years followed by 21-30 years of age group as mentioned in (Table 1).

The most common presenting feature of all bone lesions was pain (96 cases) followed by joint movement restriction (89 cases). The commonest site of all bone lesions in this study was lower end of femur with 25 cases (30.49\%) followed by proximal end of tibia (20.73\%) (Table 2). Among Non-neoplastic lesions, Chronic Osteomyelitis (32 cases, 33.9\%) were most common followed by Tuberculosus Osteomyelitis (5 cases, 4.7\%) (Figure 1a and 1b).

The most common benign neoplasm was Giant cell tumour (10 cases). The most common malignant neoplasm was Osteosarcoma (7 cases).

\section{Discussion}

Histopathological examination is the "gold standard" for definite diagnosis of bone lesions [1]. This study describes the pattern and frequencies of bone lesions including non- neoplastic (infectious), benign and malignant neoplasms.

The benign lesions (including non-neoplastic and neoplastic) were 86 cases $(81.2 \%)$ and malignant (primary and secondary) were 20 cases (18.8\%) This data correlated with the other studies mentioned in (Table 3) $[1,3,4,10,11]$.

In this study the age of patients varied from 9 years to 81 years. The mean age was 29.72 years. There was an overall male preponderance with a male to female ratio of 1.35:1. These results were comparable to various studies as mentioned in (Table 4). Similar results were reported in studies done by $[1,3,4,11]$ Jain $S$, et al. found a male to female ratio of 0.53:1.

The second decade was the commonest age group involved in our study, which correlated with other studies $[1,3,4,11-15]$.

The commonest site of all bone lesions in this study was lower end of femur, 25 cases (30.49\%) followed by proximal end of tibia (20 $.73 \%)$, which parallels with the results of other studies [1,4,11-15].

Table 1. Gender wise distribution of bone Lesions

\begin{tabular}{|c|c|c|c|c|c|}
\hline Sr. No. & Histological Type & Males & Females & Total & M:F \\
\hline I. & Infectious etiology & & & & \\
\hline 1. & Subacute pyogenic osteomyelitis & 1 & 1 & 2 & $1: 1$ \\
\hline 2. & Chronic osteomyelitis & 25 & 11 & 32 & $2.3: 1$ \\
\hline 3. & Tuberculous osteomyelitis & 3 & 2 & 5 & $1.5: 1$ \\
\hline II. & CHONDROGENIC TUMORS & & & & \\
\hline \multirow[t]{3}{*}{1.} & Benign & & & & \\
\hline & a. Osteochondroma & 5 & 2 & 7 & $2.5: 1$ \\
\hline & b. Chondroma & 2 & 2 & 4 & $1: 1$ \\
\hline \multirow[t]{2}{*}{2.} & Intermediate & & & & \\
\hline & a. Chondroblastoma & 0 & 3 & 3 & $0: 3$ \\
\hline \multirow[t]{2}{*}{3.} & Malignant & & & & \\
\hline & a. Chondrosarcoma & 1 & 2 & 3 & $1: 2$ \\
\hline III. & OSTEOGENIC TUMORS & & & & \\
\hline \multirow[t]{2}{*}{1.} & Benign & & & & \\
\hline & a. Osteoid osteoma & 2 & 2 & 4 & $1: 1$ \\
\hline \multirow[t]{2}{*}{2.} & Intermediate & & & & \\
\hline & a. Osteoblastoma & 0 & 2 & 2 & $0: 2$ \\
\hline \multirow[t]{2}{*}{3.} & Malignant & & & & \\
\hline & a. Osteosarcoma & 4 & 3 & 7 & $1.3: 1$ \\
\hline \multirow[t]{2}{*}{ IV. } & FIBROGENIC TUMOURS & & & & \\
\hline & Fibroma of bone & 1 & 1 & 2 & $1: 1$ \\
\hline $\mathbf{V}$ & EWINGS SARCOMA & 2 & 1 & 3 & $2: 1$ \\
\hline VI. & HAEMATOPOIETIC NEOPLASMS & & & & \\
\hline 1. & Plasma cell myeloma & 2 & 0 & 2 & 2:0 \\
\hline \multirow[t]{2}{*}{ VII. } & \multicolumn{5}{|l|}{ GIANT CELL TUMOURS } \\
\hline & Giant cell tumour & 5 & 5 & 10 & $1: 1$ \\
\hline VIII & \multicolumn{5}{|l|}{ NOTOCHORDAL TUMOURS } \\
\hline \multirow[t]{2}{*}{1} & Malignant & & & & \\
\hline & Chordoma & 2 & 1 & 3 & $2: 1$ \\
\hline IX & MISCELLANEOUS LESIONS & & & & \\
\hline \multirow[t]{2}{*}{1.} & Benign & & & & \\
\hline & Osteofibrous dysplasia & 1 & 2 & 3 & $1: 2$ \\
\hline \multirow[t]{3}{*}{2.} & Intermediate & & & & \\
\hline & Aneurysmal bone cyst & 2 & 1 & 3 & $2: 1$ \\
\hline & Langerhans cell histiocytosis & 0 & 1 & 1 & $0: 1$ \\
\hline \multirow[t]{2}{*}{$\mathbf{X}$} & MISCELLANEOUS TUMOURS & & & & \\
\hline & Adamantinoma & 0 & 2 & 2 & $0: 2$ \\
\hline \multirow[t]{2}{*}{ XI. } & Metastasis & 1 & 3 & 4 & $1: 3$ \\
\hline & Total & $61(57.5 \%)$ & $45(42.5 \%)$ & $106(100 \%)$ & $1.35: 1$ \\
\hline
\end{tabular}


Table 2. Common presentation of bone lesions

\begin{tabular}{|c|c|c|c|c|c|c|c|}
\hline Sr No. & Histological types & Pain (\%) & $\begin{array}{c}\text { Swelling } \\
(\%)\end{array}$ & Sinus/ Ulcers (\%) & Fracture (\%) & $\begin{array}{c}\text { Trauma } \\
(\%)\end{array}$ & $\begin{array}{l}\text { Joint movement } \\
\text { Restriction (\%) }\end{array}$ \\
\hline 1. & Osteomyelitis & $32(100)$ & $23(72)$ & $2(6.3)$ & $7(22)$ & $11(34)$ & $28(87.5)$ \\
\hline 2. & Tuberculous osteomyelitis & $5(100)$ & $4(80)$ & $1(20)$ & $2(40)$ & 0 & $4(80)$ \\
\hline 3. & Benign chondrogenic tumors & 11(100) & $10(91)$ & 0 & 0 & $1(0.9)$ & $10(91)$ \\
\hline 4. & Intermediate chondrogenic tumors & $3(100)$ & $3(100)$ & 0 & $1(33.3)$ & $1(33.3)$ & $3(100)$ \\
\hline 5. & Malignant chondrogenic tumors & $1(33.3)$ & $3(100)$ & 0 & 0 & 0 & $3(100)$ \\
\hline 6. & Benign osteogenic tumors & $5(100)$ & $4(80)$ & 0 & 0 & 0 & $4(80)$ \\
\hline 7. & Intermediate osteogenic tumors & $2(100)$ & $2(100)$ & 0 & 0 & 0 & $2(100)$ \\
\hline 8. & Malignant osteogenic tumors & $7(100)$ & $6(86)$ & $2(28.6)$ & $1(14.3)$ & $1(14.3)$ & $6(86)$ \\
\hline 9. & Fibroma of bone & $2(100)$ & $1(50)$ & 0 & 0 & 0 & $2(100)$ \\
\hline 10. & Plasma cell myeloma & $2(100)$ & $1(50)$ & 0 & 0 & 0 & $2(50)$ \\
\hline 11. & Giant cell tumour & $8(80)$ & $9(90)$ & 0 & 0 & $2(20)$ & $9(90)$ \\
\hline 12. & Chordoma & $3(100)$ & $2(66.6)$ & 0 & 0 & 0 & $2(66.6)$ \\
\hline 13. & Osteofibrous dysplasia & $1(33.3)$ & $3(100)$ & 0 & & $1(33.3)$ & $3(100)$ \\
\hline 14. & Aneurysmal bone cyst & $2(66.6)$ & $3(100)$ & 0 & 0 & 0 & $2(66.6)$ \\
\hline 15. & Langerhans cell histiocytosis & $1(100)$ & $1(100)$ & 0 & 0 & $1(100)$ & $1(100)$ \\
\hline 16. & Ewings sarcoma & $3(100)$ & $3(100)$ & 0 & 0 & 0 & $2(66.6)$ \\
\hline 17. & Adamantinoma & $2(100)$ & $2(100)$ & 0 & 0 & 0 & $2(100)$ \\
\hline \multirow[t]{2}{*}{18.} & Metastasis & $4(100)$ & $1(25)$ & 0 & $3(75)$ & $1(25)$ & $4(100)$ \\
\hline & Total & 96 & 82 & 5 & 14 & 19 & 89 \\
\hline
\end{tabular}

Table 3. Distribution of bone tumours according to WHO classification

\begin{tabular}{|c|c|c|c|}
\hline Sr. No. & Histological Type & Number & Frequency $(\%)$ in the total bone lesions in our study \\
\hline I. & CHONDROGENIC TUMORS & & \\
\hline \multirow[t]{3}{*}{1.} & Benign & & \\
\hline & a. Osteochondroma & 7 & $6.6 \%$ \\
\hline & b. Chondroma & 4 & $3.8 \%$ \\
\hline \multirow[t]{2}{*}{2.} & Intermediate & & \\
\hline & a. Chondroblastoma & 3 & $2.8 \%$ \\
\hline \multirow[t]{2}{*}{3.} & Malignant & & \\
\hline & a. Chondrosarcoma & 3 & $2.8 \%$ \\
\hline II. & OSTEOGENIC TUMORS & & \\
\hline \multirow[t]{2}{*}{1.} & Benign & & \\
\hline & a. Osteoid osteoma & 4 & $3.8 \%$ \\
\hline \multirow[t]{2}{*}{2.} & Intermediate & & \\
\hline & a. Osteoblastoma & 2 & $1.9 \%$ \\
\hline \multirow[t]{2}{*}{3.} & Malignant & & \\
\hline & a. Osteosarcoma & 7 & $6.6 \%$ \\
\hline \multirow[t]{2}{*}{ III } & FIBROGENIC TUMORS & & \\
\hline & Fibroma of bone & 2 & $1.9 \%$ \\
\hline IV. & EWINGS SARCOMA & 3 & $2.8 \%$ \\
\hline V. & HAEMATOPOIETIC NEOPLASMS & & \\
\hline 1. & Plasma cell myeloma & 2 & $1.9 \%$ \\
\hline \multirow[t]{2}{*}{ VI. } & GIANT CELL TUMOURS & & \\
\hline & Giant cell tumour & 10 & $9.4 \%$ \\
\hline VII. & NOTOCHORDAL TUMOURS & & \\
\hline \multirow[t]{2}{*}{1} & Malignant & & \\
\hline & a. Chordoma & 3 & $2.8 \%$ \\
\hline VIII & MISCELLANEOUS TUMOURS & & \\
\hline \multirow[t]{2}{*}{1.} & Benign & & \\
\hline & a. Osteofibrous dysplasia & 3 & $2.8 \%$ \\
\hline \multirow[t]{3}{*}{2.} & Intermediate & & \\
\hline & a. Aneurysmal bone cyst & 3 & $2.8 \%$ \\
\hline & b. Langerhans cell histiocytosis & 1 & $0.9 \%$ \\
\hline \multirow[t]{2}{*}{ IX } & MISCELLANEOUS LESIONS & & \\
\hline & a. Adamantinoma & 2 & $1.9 \%$ \\
\hline \multirow[t]{2}{*}{$\mathbf{X}$} & Metastasis & 4 & $3.7 \%$ \\
\hline & Total & 63 & $59.4 \%$ \\
\hline
\end{tabular}


Table 4. Frequency of benign and malignant tumours in various studies

\begin{tabular}{|c|c|c|c|}
\hline Sr. No & Studies & $\begin{array}{c}\text { Giant cell tumor commonest benign } \\
\text { neoplastic lesion }\end{array}$ & $\begin{array}{c}\text { Osteochondroma 2nd commonest benign } \\
\text { neoplastic lesion }\end{array}$ \\
\hline 1 & S Bamanikar et al, 2015 [1] & $16(19.51 \%)$ & $5(21.42 \%)$ \\
\hline 2 & S Jain et al, 2011 [15] & $24(20.51 \%)$ & $26(22.22 \%)$ \\
\hline 3 & Abdulkarem FB et al, 2009 [11] & $18(23.4 \%)$ & $6(33.3 \%)$ \\
\hline 4 & B Wamisho et al, 2010 [4] & $22(10.73 \%)$ & $22(10.73 \%)$ \\
\hline 5 & Present Study & $10(9.43 \%)$ & $7(8.53 \%)$ \\
\hline
\end{tabular}

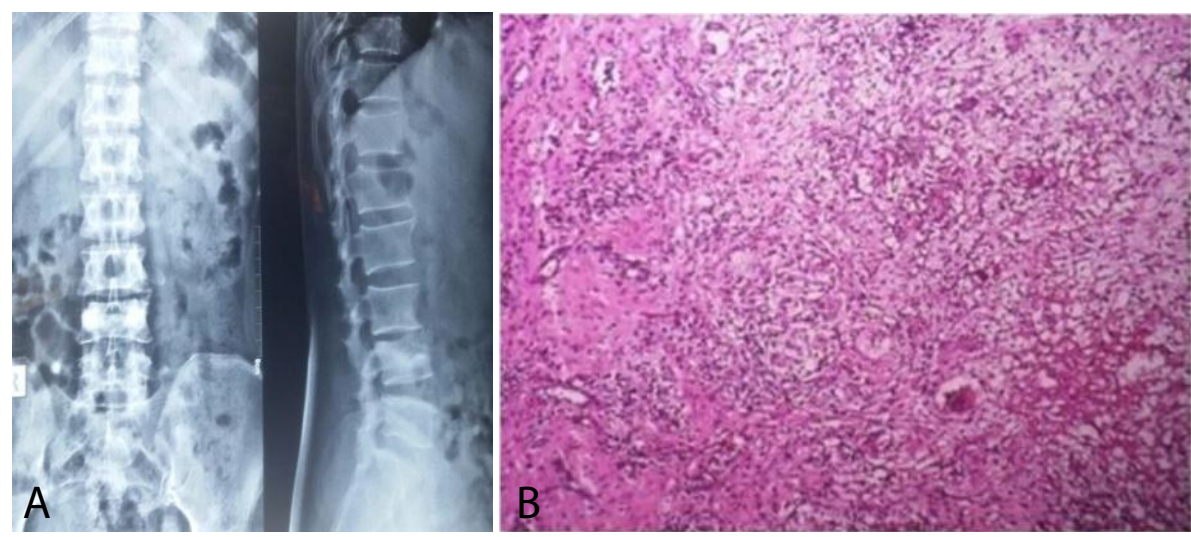

Figure 1. Tuberculous Osteomyelitis

Figure 1a. $\mathrm{X}$ ray spine showing blurred paradiscal margins and sclerosis of vertebral bodies

Figure 1b. Photomicrograph showing Tuberculous lesion of bone showing well formed granulomas. (Hematoxyilin and eosin stain 10X)
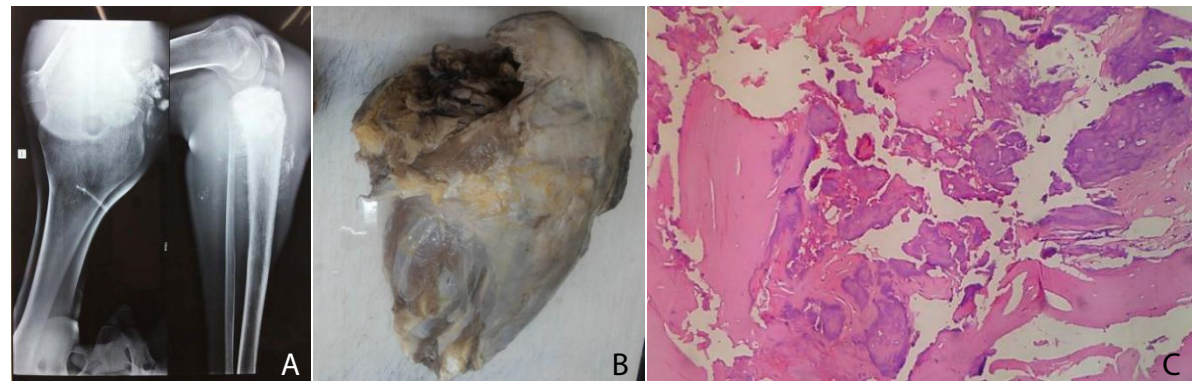

Figure 2. Osteosarcoma

Figure 2a. $\mathrm{X}$ ray showing mixed lytic and blastic lesion at upper end of tibia

Figure 2b. Gross image showing growth involving upper end of tibia

Figure 2c. Photomicrograph showing abundant osteoid production along with hyaline cartilage. (Hematoxyilin and eosin stain 40x)
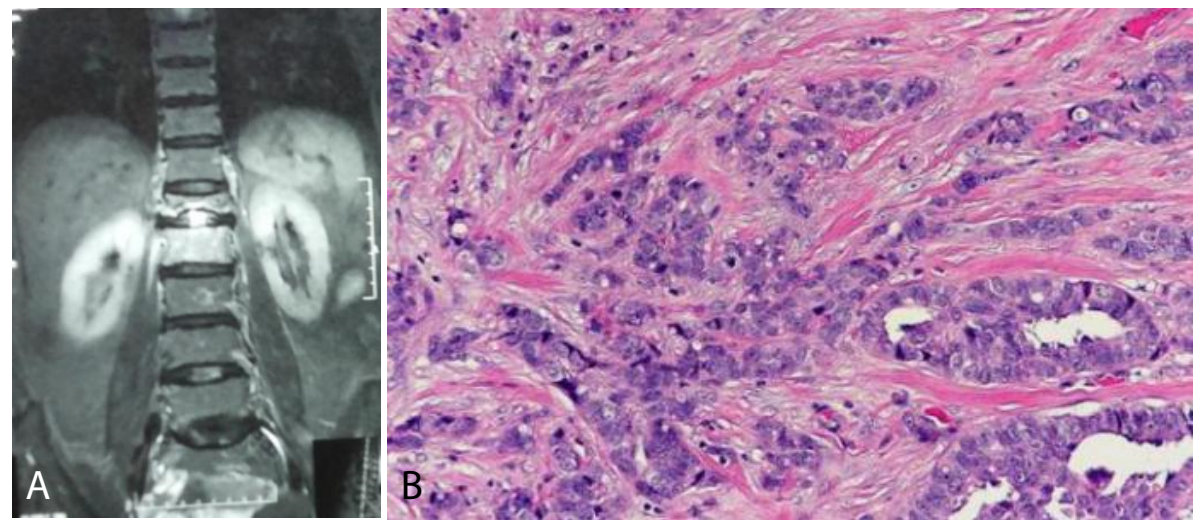

Figure 3. Metastatic deposits of malignancy

Figure 3a. MRI spine showing sclerosis and lytic lesion at T12 vertebrae

Figure 3b. Photomicrograph showing metastasis of invasive ductal carcinoma of breast in bone. (Hematoxyilin and eosin stain 40x) 
The most common benign tumour in this study was giant cell tumour (10 cases, $9.43 \%$ ) followed by Osteochondroma ( 7 cases, $6.6 \%$ ). We had $10(9.43 \%)$ cases of giant cell tumours in our study. Most of the cases were seen in 11-20 years of age with Male to female ratio of 1:1. The most common site of presentation was radius ( 5 cases, $4.7 \%)$. Most of the lesions presented radiologically as a lytic lesion in the bone with surrounding reactive bone. These findings correlated with the findings of above reference studies.

In our study, malignant lesions included 7 cases (6.9\%) of Osteosarcoma, 3 cases (2.8\%) of Chondrosarcoma and Ewing's sarcoma each. Most of the cases of Osteosarcoma were reported in 11- 20 years of age. The commonest site was femur. In other studies, it ranged in frequency with osteosarcoma ranging from $8.53 \%$ to $35.14 \%$ (Figure 2a,2b and 2c). Patients with Osteosarcoma generally present to the hospital very late (average 4-5 months) after onset of symptoms. Increased awareness and improved referral systems may decrease this delay and can help for proper treatment [4].

Of the 4 cases of metastatic lesions in our study, epithelial malignancies were most common (3 cases, 2.9\%) to metastasize followed by soft tissue malignancy (Figure 3a,b). The primary sites for the epithelial metastasis were from breast, colon and kidney. The prevalence of multiple primary epithelial malignant neoplasms varies from $0.734 \%$ to $11.7 \%$. The case of metastatic soft tissue tumour was of, 13 year old female patient who presented with difficulty in walking. Patient had pathological fracture neck femur and greater trochanter. Biopsy revealed features of Liposarcoma. Extensive immunohistochemical staining was performed. The tumour cells were immune-negative for S-100 protein, CDK- 4, CD 68, CD 163, Cytokeratin, EMA, Melan A, LCA, Desmin, SMA, Calretenin, Inhibin, Synaptophysin and Chromoganin A. Thus ruling out other differential diagnosis, the features were compatible with a pleomorphic liposarcoma metastasizing to the bone.

\section{Conclusion}

In conclusion, this study showed that primary bone lesions were mainly benign, occurred predominantly in the second decade of life with a male preponderance. Chronic Osteomyelitis, Giant cell tumour and Osteosarcoma were the most common non-neoplastic, benign and primary malignant bone lesions, respectively. Epithelial malignancies were the most common primary tumours to metastasize to bone. Since the exact diagnosis of bone tumours is at times difficult, a joint approach integrating clinical, radiological and histopathological findings is necessary to increase accuracy $[4,10]$. Histopathology is the gold standard for the precise diagnosis of the vast number of bone lesions $[3,12,13]$. If the diagnosis is not confirmed by histology, then there is a risk of inappropriate surgery being carried out $[11,14]$. The clinical and pathologic spectrum of bone lesions seen at our centre were similar to those reported from other national and international studies.

\section{References}

1. Bamanikar S, Pagaro P, Kaur P, Chandanwale S, Bamanikar A, et al. (2015) Histopathological Study of Primary Bone Tumours and Tumour-Like Lesions in a Medical Teaching Hospital. JKIMSU 4: 46-55.

2. Bjorn R (1994) Bone Embryology. Anat Embryol 189: 19-24.

3. Deoghare SB, Prabhu MH, Ali SS, Inamdar SS (2017) Histomorphological Spectrum of Bone Lesions at Tertiary Care Centre Int. J. Life. Sci. Scienti. Res 3: 980-985.

4. Wamisho B, Admasie D, Negash B, Tinsay M (2009) Osteosarcoma of limb bones: a clinical, radiological and histopathological diagnostic agreement at Black Lion Teaching Hospital, Ethiopia. Malawi Med J 21: 62-65. [Crossref]

5. Johnson LC (1953) A general theory of bone tumors. Bull NY Acad Med 29: 164-171 [Crossref]

6. Moodie RL (1923) Paleopathology. An Introduction to the Study of Ancient Evidences of Disease. pp: 567-574.

7. Saanna, Bovee J, Hornick J, Lazar A (2013) Who classification of tumors of Soft Tissue and bone $4: 5-7$.

8. Meltzer PS, Kallioniemi A, Trent JM (2002) History of cancers 93: 113-115.

9. Peltier LF (1985) Historical note on bone and soft tissue sarcoma. J Surg Oncol 30: 201-205. [Crossref]

10. Chaurasia BD (2013) Human Anatomy: Regional and applied dissection and clinical 7: 2-9.

11. Abdulkarem FB, Eyesan SU, Akinde OR, Ezembakwe ME, Nnodu OE (2007) Pathological study of Bone Tumours at the National Orthopaedic Hospital, Lagos, Nigeria. West African J Medicine 26: 306-11.

12. Singh M, Singh S, Jain J, Singh KT (2010) Chronic suppurative osteomyelitis of maxilla mimicking actinimycotic osteomyelitis: A rare case report. Natl J Maxillofac Surg 1:153-156. [Crossref]

13. Marx R (1991) Chronic osteomyelitis of the jaws. Oral Maxillofac Clin North Am 14. 3: $367-381$.

15. Jones A, Isaacs D (2013) Systematic review of duration and choice of systemic antibiotics therapy for acute haematogenous bacterial osteomyelitis in children. $J$ Paediatr Child Health 49: 760-768.

16. Jain KS, Ravishankar RM, Rupakumar CS, Gadiyar HB, Manjunath GV (2011) Bone tumors in a tertiary care hospital of south India: A review 117 cases. IJMPO 32: 82-85.

Copyright: (C2019 Kokode D. This is an open-access article distributed under the terms of the Creative Commons Attribution License, which permits unrestricted use, distribution, and reproduction in any medium, provided the original author and source are credited. 